\title{
APPLICATION OF TECHNOLOGY MANAGEMENT STRATEGIES AND METHODS TO IDENTIFY AND ASSESS CLEANER PRODUCTION OPTIONS: CASES IN THE SOUTH AFRICAN AUTOMOTIVE INDUSTRY
}

\author{
A.K. Pandey ${ }^{1}$ and A.C. Brent ${ }^{1,2}$ \\ ${ }^{1}$ Graduate School of Technology Management \\ University of Pretoria, South Africa \\ ${ }^{2}$ Resource Based Sustainable Development \\ NRE, CSIR \\ alan.brent@up.ac.za
}

\begin{abstract}
Environmental degradation is a burgeoning problem owing to the continual expansion of industrial production, and high-levels of energy and material consumption associated with economic growth. Cleaner Production (CP) is a preventive environmental approach, aimed at increasing resource efficiency and reducing the generation of pollution and waste at source. $\mathrm{CP}$ is being implemented globally and in SA, but it is not just an environmental initiative; it also supports other productivity-oriented programmes and strategies. The research study summarised in this paper assessed CP improvement options using two different Technology Management (TM) methods. The objective was to develop a better understanding of CP from a TM perspective. Data was collected through direct participation in case studies within the SA automotive industry. The case studies identified $\mathrm{CP}$ focus areas and improvement techniques. Results from the TM assessment were used to suggest strategies to benefit managers of companies and other stakeholders.
\end{abstract}

\section{OPSOMMING}

Die degenerasie van die omgewing is 'n groeiende probleem weens die toenemende industriële produksie en hoë vlakke van energie- en materiaalgebruik geassosieer met ekonomiese groei. Skoner Produksie (SP) is ' $n$ voorkomende omgewingsaanslag gemik op verhoging van hulpbroneffektiwiteit en die vermindering van besoedeling en afval by die oorsprong. SP word wêreldwyd geimplementeer, ook in Suid-Afrika, maar nie slegs as ' $n$ omgewingsinisiatief nie; dit ondersteun ook ander produktiwiteitsprogramme en -strategieë. Die navorsing het SP verbeteringsmoontlikhede evalueer mbv twee verskillende metodes van Tegnologiebestuur (TB). Die rede vir die studie was om SP beter te verstaan van 'n TB-perspektief. Data is ingesamel via direkte betrokkenheid in gevallestudies in die SA motorvervaardigingsindustrie. Die studies het SP fokusareas en verbeteringstegnieke uitgewys. Die resultate van die TB-evaluering is gebruik om strategieë voor te stel vir bestuurders van maatskappye en ander betrokke partye.

${ }^{1}$ The author was enrolled for the M Eng (Technology Management) degree in the Department of Engineering and Technology Management, University of Pretoria. 


\section{INTRODUCTION}

The challenge of environmental degradation and the need for sustainable industrial development brings forth a growing awareness in the industrial sector to do more than clean up existing pollution. Environmental protection policy has traditionally embraced the pollution control technology that captures waste at the end-of-pipe and disposes the waste through dilution or land filling. In recent years the limitations of this approach have become increasingly evident with the rising awareness of global environmental risks, growth of waste volumes, and the limits of waste disposal to land, sea and air; together with the realisation that end-of-pipe solutions to pollution simply displace the problems elsewhere or create entirely new environmental hazards. This prompted leading firms and researchers to look for a new model of industrial activity based on the minimisation of waste, energy saving, and the reduction of resources used in production.

Cleaner Production (CP) is an effective tool to address environmental problems in order to attain sustainable development. The international Agenda 21 for sustainable development, established by the United Nations in 1992, subsequently nominated Cleaner Production (CP) as the methodology industry should use to develop sustainable development policies and strategies [1]. Figure 1 provides an overview of the growing trend towards CP and sustainable development. CP is an integrated pollution control and prevention approach that conserves resources, minimises waste generation and energy use, and is based on the comprehensive analyses of process and product impacts on the environment.

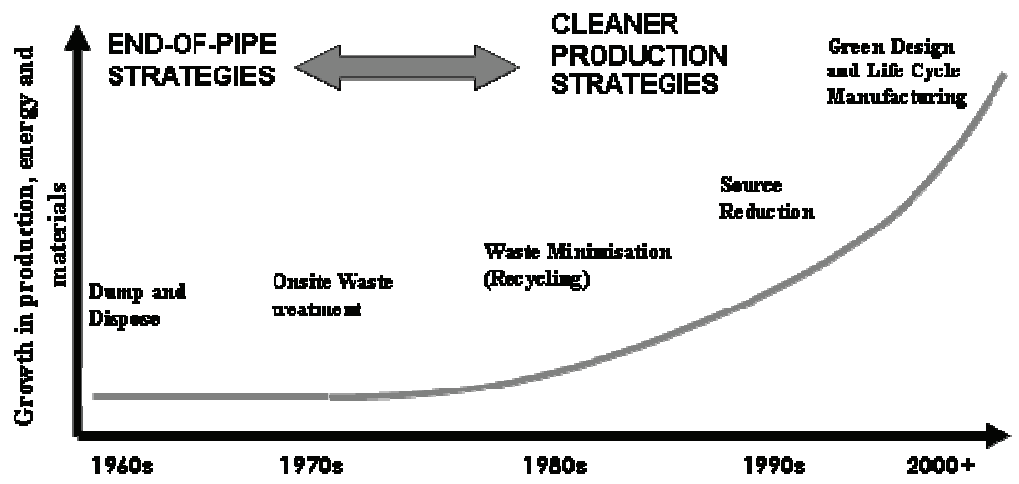

Figure 1: The shift towards Cleaner Production (CP) [1]

\subsection{Cleaner Production (CP) landscape in South Africa}

Cleaner Production (CP) is a subsidiary element of South Africa's commitment to sustainable development. The World Summit on Sustainable Development, held in South Africa during 2002, placed sustainable development high on international, regional and local agendas. The global commitment to sustainable development was 
contained in the Summit Declaration, entitled the 'The Johannesburg Plan of Action', which South Africa is in the process of implementing. This plan encourages sustainable consumption and production [1].

One of the outcomes of the Summit was the formation of the United Nations Industrial Development Organisation (UNIDO) National CP Centre (NCPC) [2], formed by an agreement between the Department of Trade and Industry (DTI), the Council for Scientific and Industrial Research (CSIR), UNIDO, and the donor countries of Austria and Switzerland. The objective of this Centre has been to stimulate the wider use of CP in South Africa with partnership between Government and other major role players such as industry, agriculture, mining, and the consumer [1].

Overall, there has been a growing trend of CP-related activities within the national economic development arena. Whereas the private sector is more focused on the practical industry-based implementation of $\mathrm{CP}$ projects, the public sector has been actively involved in a broad array of activities including research, policy formulation, project financing, and implementation. Moreover, local academic and research institutions and privately owned consulting firms are also actively conducting CP-related research, thereby creating awareness and documenting local and international best practices regarding the emerging $\mathrm{CP}$ phenomenon and its potential benefits to the participating industries. However, there are no effective incentives to encourage all waste producers to adopt CP processes and minimise waste generation. Recycling and reuse are not systematically encouraged, although $\mathrm{CP}$ technologies have been identified as a priority in the Integrated Pollution and Waste Management Policy and the National Waste Management Strategy [3]. With regards to the promotion of $\mathrm{CP}$ technologies, the South African environmental legislative framework is generally fragmented, with no consolidated national statute relating specifically to waste management and the promotion of resource efficiency.

\subsection{Objectives of this paper}

The research on which this paper is based [4] sets out to establish a framework to assess CP technologies from a Technology Management (TM) perspective. The main objectives of this paper are consequently to:

- $\quad$ Enhance CP audits in the South African automotive manufacturing industry; and

- Increase the understanding of CP improvement options and technologies, which will assist in developing a strategy for CP in the South African automotive sector.

\section{TECHNOLOGY MANAGEMENT (TM) AND INNOVATION}

Technology Management (TM) is a process that includes planning, directing, controlling, and coordinating the development and implementation of technological capabilities to shape and accomplish the strategic and operational objectives of an organization [5]. TM includes [6]:

- $\quad$ Planning for the development of technology capabilities;

- $\quad$ Identifying key technology and its related fields for development; 
- $\quad$ Determining whether 'to buy' or 'to make', i.e. whether importation or selfdevelopment should be pursued; and

- Establishing institutional mechanisms for directing and coordinating the development of technology capabilities, and the design of policy measures for controls.

Technology plays an important role in the ability of manufacturing enterprises to compete in international markets. In order to make optimal technological investment decisions, management needs to understand how technology manifests itself in the business process and what impact it has on the manufacturing enterprise as a whole [7]. Clearly, TM should not only fulfil the management needs of a specific set of technologies within a domain and inter-domain relationship, but it should also develop the implementation strategies according to the available resources, current technologies, future markets, and socioeconomic environments [8]. Therefore, how to manage technology has become an important issue in the past few decades. The TM community has subsequently developed a wide range of methodologies and applications for both academic research and practical applications. In the South African context it has been suggested [9] that synergies between research and practical applications need special attention, which must also manifest in the assessment of CP options and technologies.

\subsection{CP and technological innovation}

Fresner [10] found that in the course of conducting CP projects, in more than $40 \%$ of companies, technological innovation was stimulated, e.g. changes in the recovery of materials and exhaust heat, and the introduction of water-based paints. For more than $60 \%$ of the surveyed consultants, eco-auditing stimulated more innovation than control by instrumentation did.

In Lithuania, CP projects resulted in the implementation of more than two hundred $\mathrm{CP}$ innovations in more than one hundred and fifty Lithuanian companies [11]. It was stressed that effective plant maintenance is becoming a high priority. It is important to ensure cost-savings at all levels that maximise productivity through implementing energy-savings. Effective and efficient maintenance are not just desirable, but fundamental to profitable business operations. Therefore, central to the environmental view of sustainable development is the concept that economic and social systems are sub-systems of the global environment [11]. According to the results of monitoring implemented $\mathrm{CP}$ innovations, the database "Implementation of CP in Lithuania" was created in 2002. This database provides the information on one hundred and sixty-eight CP innovations implemented in seventy-four companies during the last decade in different sectors of the Lithuanian economy [12]. The study stresses that CP projects take time, as they involve organizational as well as technological changes. It is not enough for consultants to locate the technological options; they also have to be effective catalysts in a process that changes attitudes in the organization. Leadership by the management is a prerequisite for successful pollution prevention projects. 


\section{ASSESSMENT FRAMEWORK}

The framework used during this study [4] is aimed at linking the conventional CP auditing process to TM practices. Figure 2 shows a basic layout of the overall framework. The process involves a CP audit of the manufacturing facility leading to identified CP technologies. Identified CP technologies are then assessed, based on TM parameters, to identify TM strategies.

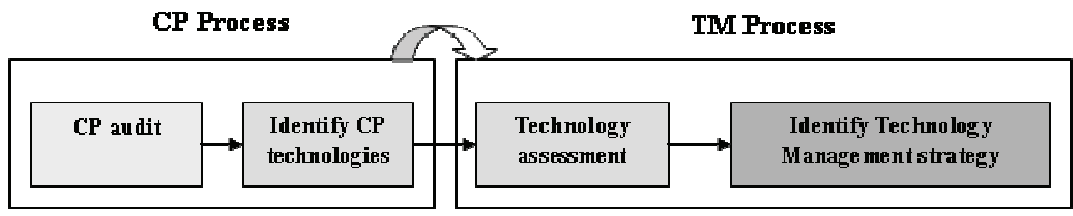

Figure 2: Introduced assessment model

\subsection{CP process component of the assessment framework}

The first step in the $\mathrm{CP}$ auditing component of the framework is to identify the target industry and/or sector. Then CP audits are performed in the operational facility by following the steps shown in Figure 3.

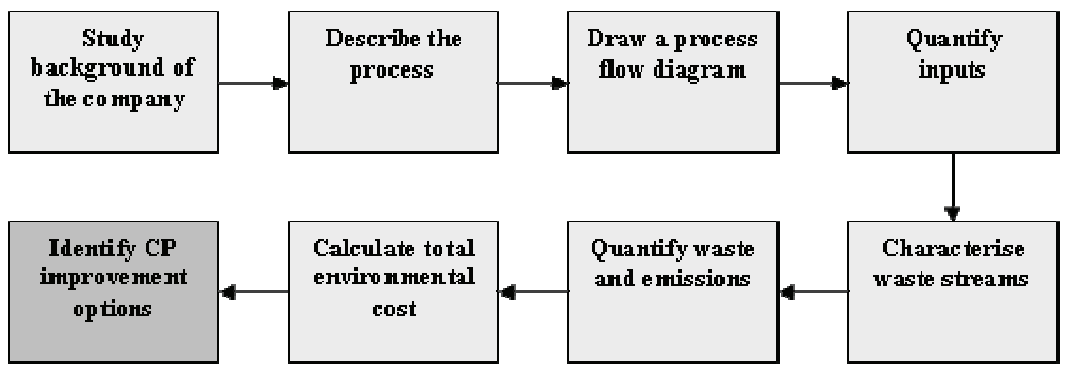

Figure 3: CP auditing process

\subsection{TM process component of the assessment framework}

Two TM approaches are utilised to assess an identified new CP technology. First, the $\mathrm{CP}$ technology is measured against five impact parameters as listed in Table 1. Second, a nine cell classification matrix for artefacts based on the technological functions has been proposed (see Table 2) [13]. The system combines the three categories of major outputs with the three manners of handling. 


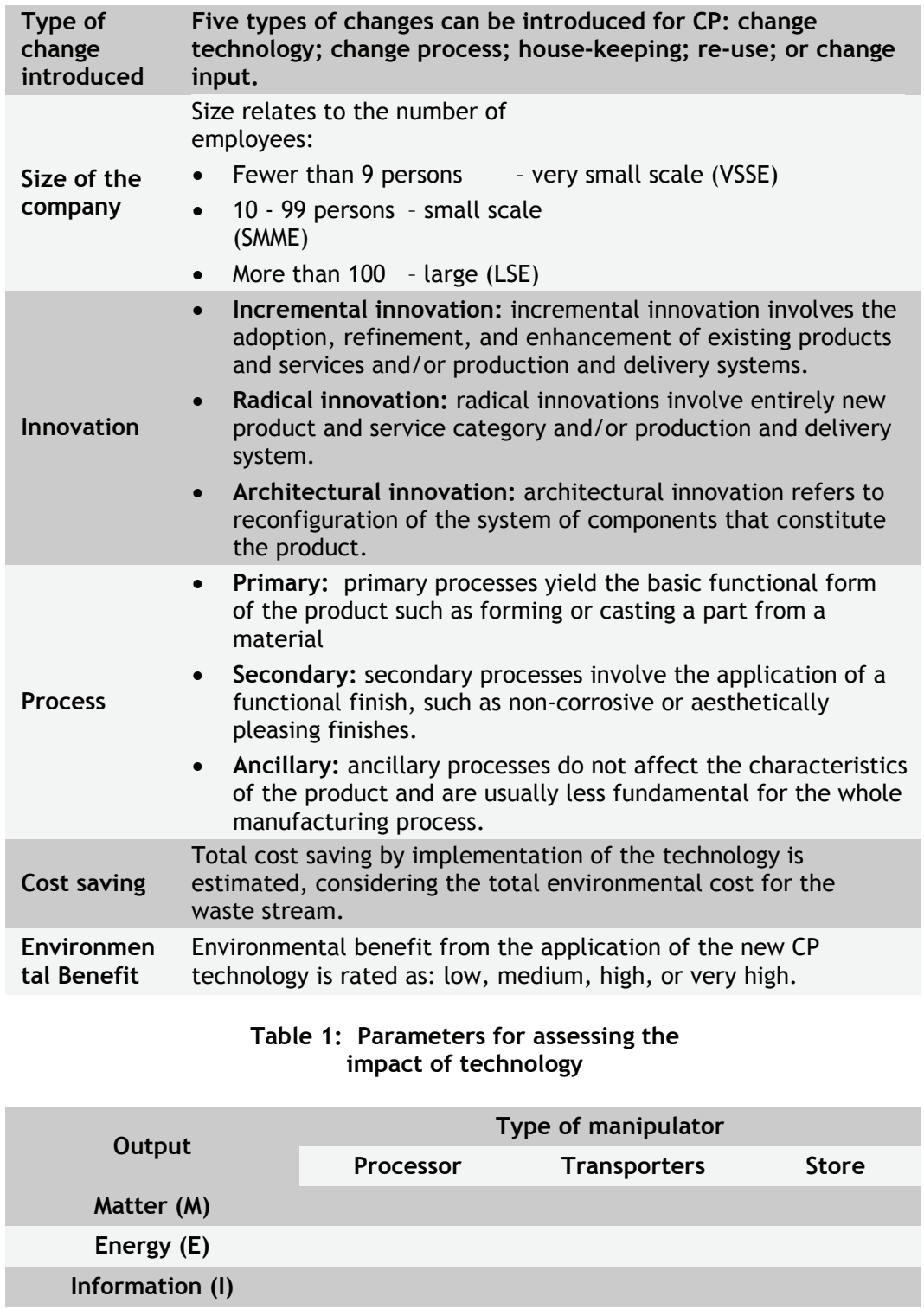

Table 2: Nine cell classification matrix to assess the functionality of a technology 


\section{RESEARCH METHODOLOGY}

A case study research methodology $[14,15,16]$ was followed in the study summarised in this paper [4]. For the purposes of this research the Waste Minimisation Club (WMC) of the Rosslyn industrial area north of Pretoria was used to identify suitable case studies. Five members of the WMC were chosen. Two to three months were spent at each facility, and relevant information was gathered from the following:

- Company records

- Interviews with personnel

- Interviews with managers

- $\quad$ Measurements and calculations of inputs and outputs

- $\quad$ Observations of production processes

Actual input and output costs were calculated based on buying and selling prices of goods and waste. Overall environmental costs of the waste streams were calculated to estimate the cost saving by each identified technology.

\subsection{CP process component of the assessment framework}

The CP analysis mainly focused on the following areas:

- $\quad$ Energy: Electricity, fuel, etc.

- Water: Effluent management (discharge and disposal), and water balances.

- $\quad$ Solid waste: Cardboard, process waste (plastics, rubber), wood, etc.

Once the data had been captured, the CP auditing process was carried out as per the CP model of Figure 3:

1. Process flow diagram

2. Identify all inputs and outputs

3. Quantify inputs, outputs and waste

4. Calculate total environmental cost

5. Select most critical waste streams based on the following:
a. Size or quantity
b. Environmental cost
c. Environmental impact
d. $\quad$ CP and waste minimisation potential
e. Other

Based on the total rating of each waste stream the focus areas in the manufacturing plant were selected.

\subsection{TM process component of the assessment framework}

Once technological improvement options had been identified through the CP auditing process, the identified technologies were assessed based on the parameters 
of Table 1 - i.e. size of company, type of innovation, type of process affected, cost benefit and environmental benefit, and the nine cell classification matrix (see Table 2).

\section{RESULTS}

\subsection{CP process component of the assessment framework}

Figure 4 presents an example of the results from the CP auditing process at one company. Together with internal stakeholders at the company, any waste stream with a rating above 12 was considered critical, and had to be attended to urgently. Waste streams with a rating of less than 12 could be attended to in the medium- to long-term. Once the waste streams and focus areas were identified, the associated improvement techniques were investigated further.

\section{Focus Areas}

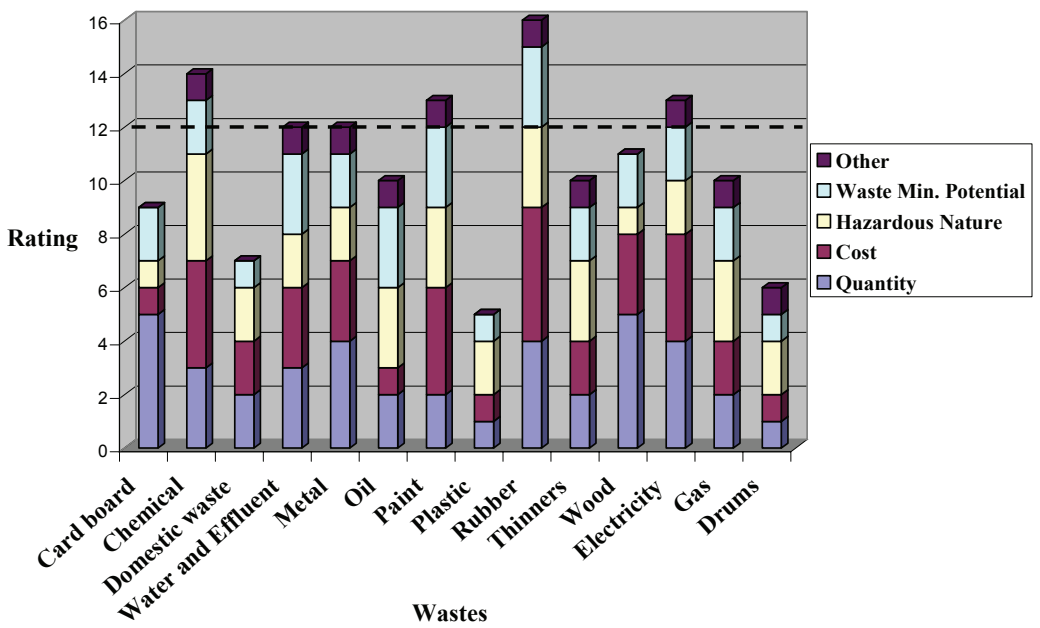

Figure 4: Example of rating various waste streams

\subsection{TM process component of the assessment framework}

Overall, the CP audits that were carried out in the five different companies identified twenty-one improvement options. Some key observations are as follows:

- $\quad$ Changes in technology (8), housekeeping (6) and process methods (3) were the most common types of changes introduced.

- $\quad 85.7 \%$ of all the options proposed were incremental innovations.

- $\quad 61.9 \%$ of all processes affected were ancillary.

- $\quad 89.6 \%$ of the improvement options yielded medium- to low-cost savings. 
- $\quad 85.7 \%$ of the improvement options showed medium to high environmental benefits.

- $\quad$ Two of the large-scale enterprises yielded $12(57.1 \%)$ of the improvement options suggested, and three SMMEs provided 9 (42.9\%) of the improvements.

Table 3 presents the 21 technologies based on the five parameters.

\begin{tabular}{|c|c|c|}
\hline Type of Change & $\begin{array}{l}\text { Number of } \\
\text { techniques }\end{array}$ & Percentage (\%) \\
\hline Change Input & 2 & 9.52 \\
\hline Change Technology & 8 & 38.10 \\
\hline Change process & 3 & 14.29 \\
\hline Product Change & 0 & 0.00 \\
\hline Internal re-use & 2 & 9.52 \\
\hline Housekeeping & 6 & 28.57 \\
\hline \multicolumn{3}{|l|}{ Innovation } \\
\hline Radical & 1 & 4.76 \\
\hline Incremental & 18 & 85.71 \\
\hline Architectural & 2 & 9.52 \\
\hline \multicolumn{3}{|l|}{ Process } \\
\hline Primary & 5 & 23.81 \\
\hline Secondary & 3 & 14.29 \\
\hline Ancillary & 13 & 61.90 \\
\hline \multicolumn{3}{|l|}{ Cost saving } \\
\hline Low & 7 & 33.33 \\
\hline Medium & 12 & 57.14 \\
\hline High & 2 & 9.52 \\
\hline Very high & 0 & 0.00 \\
\hline \multicolumn{3}{|l|}{ Environmental benefit } \\
\hline Low & 2 & 9.52 \\
\hline Medium & 9 & 42.86 \\
\hline High & 9 & 42.86 \\
\hline Very high & 1 & 4.76 \\
\hline \multicolumn{3}{|l|}{ Size of company } \\
\hline Large & 12 & 57.14 \\
\hline SMME & 9 & 42.86 \\
\hline
\end{tabular}

Table 3: Assessment of CP technological improvement options 
The nine cell model of technology assessment (see Table 2) provided a simple and easy-to-use TM framework for technological scanning and developing a strategy. Table 4 shows the outcomes of the nine cell framework.

Classification of artefacts/technologies based on technology function shows that CP improvement options mainly result in changes to matter and energy outputs. For the South African automotive industry the energy outputs are of lesser importance.

Based on the assessment, it is noted that no information outputs in terms of processing, transportation, and storage are associated with the technological improvements. Such CP information outputs could be achieved by having innovative ways of informing the work force, and, for example, displaying the information on the company website.

The results of the analysis show a high focus on waste management and minimisation. Sustainable CP would require more emphasis on energy manipulation. With the growing need for energy in the local economy and the advancement in information technology, it is essential that CP assessments focus on energy savings.

\begin{tabular}{|c|c|c|c|}
\hline \multirow{2}{*}{ Output } & \multicolumn{3}{|c|}{ Type of manipulator } \\
\hline & Processor & Transporters & Store \\
\hline Matter & $\begin{array}{c}A, C, D, E, F, J, \\
L, M, R, S\end{array}$ & $\mathrm{G}, \mathrm{H}, \mathrm{K}, \mathrm{P}, \mathrm{Q}, \mathrm{T}$ & $\mathrm{I}, \mathrm{U}$ \\
\hline Energy & B & $\mathrm{N}$ & 0 \\
\hline $\begin{array}{r}\text { Information } \\
\text { (I) }\end{array}$ & & & \\
\hline
\end{tabular}

Table 4: Classification of artefacts based on technology functions

Note: Technologies have been identified by letters of the alphabet assigned to each option in Table 1.

\section{TM STRATEGY}

The following can be suggested from the application of the assessment framework:

- More architectural and radical innovations options could be looked at in reducing process waste and minimising waste.

- $\quad$ CP technologies should also aim at having more influence at primary and secondary process levels.

- Information and energy outputs of CP options (artefacts) should be considered more.

- $\quad$ Management should use CP as a strategic business tool rather than an Environmental Management System (EMS) tool.

Most of the technologies identified through the CP assessments could be analysed using the TM framework model presented in section 3. However, CP assessment 
methods could be modified to incorporate the requirements of the TM framework to yield a better understanding and sustainability of the identified technologies.

\section{CONCLUSION}

Owing to a low focus on environmental protection and a high focus on economic growth in developing countries such as South Africa, the development of cleaner technologies is slow. However, it is essential to conduct Cleaner Production (CP) assessments in companies to identify high-risk areas and develop technologies to improve environmental performance along with cost savings. This paper suggests that $\mathrm{CP}$ processes should be connected to the business processes in a company for effective implementation of $\mathrm{CP}$ options. It is subsequently proposed that a Technology Management (TM) framework be used to fill this gap and provide a strategy for CP technologies. The research demonstrates the TM approach towards CP technologies. CP options were identified in the South African automotive manufacturing sector through a systematic CP audit process and subsequent TM assessment methods.

The assessment of the five TM parameters in the framework showed that CP improvement technologies lean towards the following:

$\begin{array}{lll}\text { - } & \text { Type of change } & \text { Technology } \\ \text { - } & \text { Innovation } & \text { Incremental } \\ \text { - } & \text { Process } & \text { Ancillary } \\ \text { - } & \text { Cost saving } & \text { Medium } \\ \text { - } & \text { Environmental benefit } & \text { Medium / High } \\ \text { - } & \text { Size of company } & \text { Larger }\end{array}$

The results highlight that, in the South African automotive sector, technological growth can be achieved through CP through mainly incremental innovations in secondary process. However, to a lesser extent, some radical changes have also been proposed and primary processes improved.

Other sectors of the economy should also be studied to understand the differences and similarities of CP audits and CP technologies. It is therefore envisaged that the introduced assessment framework will pave the way for further research into $\mathrm{CP}$ technologies using TM approaches.

\section{REFERENCES}

[1] Department of Environmental Affairs and Tourism (DEAT). 2004. Assessment ofthe status quo of Cleaner Production in South Africa. Final report, Pretoria.

[2] National Cleaner Production Centre (NCPC). Website: http://www.ncpc.co.za, accessed 30 July 2007.

[3] Department of Environmental Affairs and Tourism (DEAT). National waste management strategy implementation project website. Website: http://www.environment.gov.za/nwmsi/index.html, accessed 30 July 2007. 
[4] Pandey, A.K. 2007. Identification and assessment of CP technologies and appropriate technology management strategies and methods in the South African vehicle industry. Masters dissertation, Graduate School of Technology Management, University of Pretoria, Pretoria.

[5] Task Force on Management of Technology. 1987. Management of technology: The hidden competitive advantage. National Academy Press, Washington, DC, p 9.

[6] Visser, W. 2002. Changes needed in the approach to environmental management. KPMG Environmental Consulting Unit. Website: http://www.kpmgadministrators.co.za/modules/library/, accessed on 31 July 2007.

[7] Pretorius, M.W. and de Wet, G. 2000. A model for the assessment of new technology for the manufacturing enterprise. Technovation, 20(1), pp 3-10.

[8] Linn, R.J., Zhang, W., and Li, Z.Y. 2000. An intelligent management system for TM. Computers and Industrial Engineering, 38, pp 397-412.

[9] de Wet, G. 2000. Emerging from the technology colony: A view from the South. Graduate School of Technology Management, University of Pretoria, Available from: https://www.up.ac.za/dspace/handle/2263/1703.

[10] Fresner, J. 1998. Cleaner Production as a means for effective environmental management. Journal of Cleaner Production, 6, pp 171-179.

[11] Staniskis, J.K. and Stasiskiene, Z. 2006. Environmental management accounting in Lithuania: Exploratory study of current practices, opportunities and strategic intents. Journal of Cleaner Production, 14(14), pp 1252-1261.

[12] Kliopova, S.I. and Staniskis, J.K. 2006. The evaluation of Cleaner Production performance in Lithuanian industries. Journal of Cleaner Production, 14(18), pp $1561-1575$.

[13] van Wyk, R.J. 1988. Management of Technology: New frameworks. Technovation, 7, pp 341-351.

[14] Feagin, J., Orum, A., and Sjoberg, G. (eds.). 1991. A case for case study. University of North Carolina Press, Chapel Hill, North Carolina.

[15] Yin, R. 1984. Case study research: Design and methods. First edition, Sage Publishing, Beverly Hills, California.

[16] Stake, R. 1995. The art of case research. Sage Publications, Newbury Park, California. 